DOI 10.4467/25439561KSR.21.006.14417

\author{
AleKsander PosacKi SJ (D https://orcid.org/0000-0003-4482-4549
}

Collegium Verum

Warszawa

\title{
INFILTRACJA IDEOLOGII GNOSTYCKICH I EZOTERYCZNYCH W TWÓRCZOŚCI WŁODZIMIERZA SOŁOWJOWA I HELENY BŁAWATSKIEJ
}

\author{
THE INFILTRATION OF GNOSTIC AND ESOTERIC IDEOLOGIES IN \\ THE WORKS OF VLADIMIR SOLOVYOV AND HELENA BLAVATSKY
}

\section{Streszczenie}

Artykuł ma na celu ukazanie wpływu idei gnostyckich oraz koncepcji ezoterycznych i okultystycznych na twórczość filozofa rosyjskiego Włodzimierza Sołowjowa, a następnie - na tej bazie - porównanie podobnych teorii i praktyk duchowych Sołowjowa z twórczością ezoteryczną i praktykami duchowymi Heleny Bławatskiej, założycielki Towarzystwa Teozoficznego. Okazuje się bowiem, że pomimo istotnych różnic w obszarze filozofii, rzetelności metodologicznej, stosunku do chrześcijaństwa, można stwierdzić wiele podobieństw w sferze konceptualnej i praktycznej, nawet jeśli wydają się one powierzchowne i nieistotne. Wydaje się, że twórczość Bławatskiej i Sołowjowa mogą tworzyć jakby podobny kod kulturowy (oparty choćby na podobnym stosunku do idei gnostyckich i kabalistycznych). Sprawa wymaga jednak bardziej szczegółowych badań, zaś autor artykułu nie pretenduje do rozstrzygnięcia postawionej w artykule kwestii, a jedynie sygnalizuje dość dokładnie problem, o którym jak się wydaje - w polskiej literaturze naukowej do tej pory niewiele powiedziano.

\section{Abstract}

The article aims at emphasising the influence of Gnostic ideas as well as esoteric and occult concepts on the work of Russian philosopher Vladimir Solovyov. Furthermore, on the basis of this analysis the author tries to compare similar theories and spiritual practices of 
Solovyov with the esoteric work and spiritual practices of Helena Blavatsky, the founder of The Theosophical Society. It appears that despite significant differences in the field of philosophy, methodological reliability, and attitude to Christianity, many similarities can be found in the conceptual and practical sphere, even if they seem superficial and irrelevant. Consequently, the works of Blavatsky and Solovyov can presumably create a common cultural code (based, for example, on a comparable attitude to Gnostic and Kabbalistic ideas). The issue, however, requires some more detailed research, and the author of the article does not imply he concluded it. The article highlights the fact that the studies on this topic have been so far hardly comprehensive.

Słowa kluczowe: gnoza, ezoteryzm, okultyzm, spirytyzm, mediumizm, mistycyzm, lucyferyzm, Szatan, Włodzimierz Sołowjow, Helena Bławatska

Keywords: gnosis, esotericism, occultism, spiritism, mediumism, mysticism, luciferism, Satan, Vladimir Solovyov, Helena Blavatsky

\section{Pomiędzy Sołowjowem a Bławatską}

W opisie ezoteryzmu i gnozy w kulturze rosyjskiej odniosę się głównie do mało znanej kwestii podobieństwa niektórych koncepcji Włodzimierza Sołowjowa i ideologii Heleny Bławatskiej, a także stosowanych przez nich praktyk duchowych ${ }^{1}$. Takie podejście badawcze wydaje się istotne, gdy chodzi o głębsze rozumienie wpływu obydwojga autorów na współczesną kulturę rosyjską, a szczególnie 1. połowy dwudziestego wieku². Spróbuję przedstawić jedynie zarys tego problemu. Studium niniejsze można uznać, póki co, za rekonesans, który może otworzyć drogę do kolejnych refleksji czy badań.

Ezoteryzm (okultyzm) oraz gnoza, która jest niejako jego istotą, są dosyć szczegółowo i często omawiane w rosyjskojęzycznym piśmiennictwie naukowym, z różnych zresztą punktów widzenia ${ }^{3}$. Dosyć powszechnie uznaje się wpływ gnozy na kulturę rosyjską i praktyczne oddziaływanie na wielu jej czołowych przedstawicieli, takich jak: Sołowjow, Fiodor Dostojewski, Mikołaj Bierdiajew, Wiaczesław Iwanow czy Dymitr Mereżkowski. Temat ten poruszano także w polskiej literaturze naukowej,

\footnotetext{
${ }^{1}$ Pojęcia ideologii używam w znaczeniu neutralnym, jako synonim koncepcji czy teorii.

${ }^{2}$ Mówiąc o kulturze rosyjskiej, mam na myśli ten właśnie okres.

${ }^{3}$ Traktuję ezoteryzm jako teoretyczną bazę ,wiedzy tajemnej”, a okultyzm jako jej praktyczną realizację, np. w formie spirytyzmu. Okultyzm uważam za działanie mało twórcze oraz niebezpieczne dla człowieka i takiej interpretacji trzymam się w tym artykule. Zob. więcej na temat: A. Posacki, Ezoteryzm i okultyzm - formy dawne i nowe. Aspekty filozoficzno-teologiczne i praktyczno-duszpasterskie, Radom, Polskie Wydawnictwo Encyklopedyczne, 2009, s. 24.
} 
szczególnie w pracach Sławomira Mazurka, znawcy kultury rosyjskiej ${ }^{4}$ Mniej znana jest natomiast obecność czy wpływ innych niż gnoza idei ezoterycznych, okultystycznych czy spirytystycznych na Sołowjowa, który jest oczywisty w przypadku ideologii Bławatskiej, spirytystki i założycielki Towarzystwa Teozoficznego. Rozjaśnienie tej kwestii zbliży nas bardziej do problemu możliwego porównania twórczości Sołowjowa i Bławatskiej. Jest to tym ważniejsze, że podobieństwo Sołowjowa do Bławatskiej wykorzystywane jest przez zwolenników teozofii Bławatskiej w celu propagowania jej ideologii ${ }^{5}$.

\section{Niezamierzone podobieństwa w twórczości Sołowjowa i Bławatskiej oraz ich znaczenie w kulturze}

Podobieństwa w twórczości Włodzimierza Sołowjowa i Heleny Bławatskiej są słabo znane i raczej niedocenione. Paradoks polega na tym, że mimo faktu, iż Sołowjow zasadniczo świadomie odrzucał koncepcje Bławatskiej, to jednak na poziomie niektórych teorii oraz praktyk duchowych widzimy pewne zbieżności, które choć niezamierzone i niechciane są realnie obecne w jego piśmiennictwie. Zwykle podkreśla się różnice przekonań obojga autorów, wskazując, że odkrywcze koncepcje filozoficzne Sołowjowa nie dają się w żaden sposób porównać z niespójnym eklektyzmem światopoglądowym Bławatskiej ${ }^{6}$. Oboje pisali o teozofii, ale są to różne teozofie. Uwagę zwracają bowiem również istotne, choć zazwyczaj lekceważone, niektóre powierzchowne i niedotyczące zasadniczej myśli Sołowjowa podobieństwa. Obecne głównie w pierwszym okresie jego twórczości i stanowiące punkt odniesienia dla teozofów związanych z Bławatską autorytetem Sołowjowa ${ }^{7}$.

Sołowjow miał wielki wpływ na filozofię, teologię oraz sztukę w Rosji i na świecie, Bławatska z kolei silnie oddziaływała na literaturę i sztukę, m.in. rosyjski

${ }^{4}$ Zob. S. Mazurek, Dziedzictwo gnozy w rosyjskiej filozofii religijnej, [w:] http://www.ahf.ifispan. pl/pl/58-mazurek-gnoza [dostęp: 20.05. 2021].

${ }^{5}$ Zabiegają o to szczególnie zwolennicy Agni-Jogi (ideologii teozoficznej rodziny Rerichów, związanych z Bławatską). Zob. Д.С. Куляница, Теософия Е.П. Блаватской и русская литература и искусство (конеи XIX - середина XX века), [w:] Современное миропонимание: духовные аспекты развития культуры. Материаль ежегодной научно-практической конференции „Е.П. Блаватская и современность”, red. Ю.А. Шабанова, А.С. Пригунов, И.В. Павленко, Днепропетровск, Национальный горный университет, 2013, ss. 15-33.

${ }^{6}$ Zob. A. Кураев, Сатанизм для интеллигенщии (О Рерихах и Православии в двух томах), том 2, Христианство без оккультизма, Москва, Издательство Московского Подворья СвятоТроицкой Сергиевой Лавры, 2006, s. 295.

${ }^{7}$ Tamże, s. 299. 
symbolizm i awangardę (malarstwo Kandinsky'ego i Malewicza) ${ }^{8}$. Podobieństwa owe - nawet te powierzchowne - stworzyły jednak, nie zawsze świadomie i często tylko subiektywnie, w świadomości wielu Rosjan pewien kod kulturowy określany mianem gnostyckiego paradygmatu, który wpłynął całościowo na kulturę rosyjską w sposób trwały i znaczący9 .

\section{Znaczenie ezoteryzmu i okultyzmu w życiu oraz twórczości Sołowjowa i Bławatskiej}

Sądzi się dość powszechnie, że Sołowjow w młodości zajmował się spirytyzmem. Nie chodziło tu jednak o zwykły epizod czy nawet o krótki okres duchowego pobłądzenia. Rosyjski myśliciel poznał bowiem dogłębnie, a nawet doświadczył wszystkich możliwych form ezoteryzmu i okultyzmu, także w jego najbardziej prymitywnych formach. Wiele informacji otrzymał od swojego brata, pisarza, Wsiewołoda Sołowjowa, który posiadał gruntowną wiedzę o ezoteryzmie i okultyzmie oraz wiele pisał - także krytycznie - na ten temat. Sołowjow nie podzielał jednak radykalnego krytycyzmu brata, szczególnie w odniesieniu do Bławatskiej. Były ku temu obiektywne powody.

Jak stwierdza Konstantin Burmistrow, teksty i rękopisy z masońskiego archiwum, do którego miał dostęp rosyjski filozof w Londynie, dotyczą ogromnego bogactwa rozmaitych teorii i praktyk, odnoszących się do ezoterycznych tradycji. Są to pisma gnostyckie, alchemiczne i hermetyczne, a także dokumenty, odnoszące się do magii i teurgii. Znaczna część przebadanych przez Sołowjowa tekstów wiąże się z kabałą, co potwierdza jego szczególne zainteresowanie żydowską tradycją mistyczną $^{10}$.

Podobnie jest u Bławatskiej. Oboje czerpali wiedzę na temat kabały z tych samych źródeł, przy czym niektóre z nich, z naukowego punktu widzenia, są niewiarygodne. Według wybitnego znawcy kabały Burmistrowa, to, co Sołowjow rekomenduje jako źródło wiedzy o niej, jest dowodem jego głębokich okultystycznych zainteresowań. Chodziło tu o korzystanie z dzieła Izaaka Meiera, który w tym zakresie był także głównym autorytetem dla Bławatskiej i innych członków Towarzystwa

\footnotetext{
${ }^{8}$ Zob. Н.К. Бонецкая, Русская софиология и антропософия, Сайт „Библиотека духовной науки", http://bdn-steiner.ru/modules.php?name=Books\&go=page\&pid=302 [dostęp: 15.05.2021].

${ }^{9}$ Jednym $\mathrm{z}$ takich powierzchownych podobieństw jest fakt poszukiwania syntezy religii, filozofii i nauki, który występuje zarówno u Sołowjowa i Bławatskiej, sprawiający wrażenie istotnej paraleli.

${ }^{10}$ Zob. К.Ю. Бурмистров, Владимир Соловьев и европейский эзотеризм: проблема источников, „Соловьевские исследования” 2016, nr 2 (50), ss. 47-65.
} 
Teozoficznego. W Stowniku teozoficznym (The Theosophical Glossary) widzimy wielokrotne odniesienia do tej postaci. Tymczasem w naukowej literaturze - według Burmistrowa - odnośnie do kabały, Meier nie był znawcą tematu ${ }^{11}$.

Około połowa przejrzanych przez Rosjanina rękopisów dotyczy lóż masońskich, w tym wolnomularskich doktryn i rytuałów. Wiele z nich jest związanych z tradycją różokrzyżowców, czyli z najbardziej ezoterycznymi kręgami masonerii. Według Burmistrowa relacje Sołowjowa z masonerią wymagają osobnych badań. Jest to także ważne, gdy idzie o porównanie twórczości tego autora $\mathrm{z}$ dziełami Bławatskiej, która, częściowo związana z masonerią, była założycielką organizacji ezoterycznej znanej jako „Loża Bławatskiej”12.

Jak zauważa Burmistrow, w opublikowanych tekstach Sołowjowa praktycznie brak prac specjalnie poświęconych tematyce ezoterycznej, poza dwiema niewielkimi recenzjami dotyczącymi Bławatskiej ${ }^{13}$. Ale to nie oznacza, że rosyjski filozof nie pracował nad takimi tekstami lub też nie zamierzał ich publikować. Zachowało się wiele rękopisów z uwagami i notatkami Sołowjowa, które świadczą o jego wnikliwych badaniach oraz inspiracjach ezoteryzmem, co jest szczególnie widoczne w jego notatkach dotyczących nieopublikowanego traktatu o Sofii ${ }^{14}$.

\section{Spirytyzm i mediumizm Sołowjowa}

Szkodliwość spirytyzmu w kwestiach moralnych głosił Fiodor Dostojewski, zbliżając się do chrześcijańskiej oceny tego zjawiska. Postrzegał on spirytyzm nie jako przesąd, ale jako zabobon (superstitio), czyli fałszywą religijność, bliską idolatrii. Tadeusz Klimowicz pisze o szkodliwości społecznej spirytyzmu, którą zauważył Dostojewski, ale nie pisze o destrukcji duchowej, która w opinii rosyjskiego pisarza była najbardziej poważna ${ }^{15}$.

Jest sprawą oczywistą, że Sołowjow doświadczył szczególnie niebezpiecznego dla ducha i ciała spirytyzmu oraz mediumizmu, zarówno w teorii, jak i w praktyce.

${ }^{11}$ Tamże.

${ }^{12}$ Zob. N. Wójtowicz, Masoneria, Warszawa, Verbinum, 2006, s. 72.

${ }^{13}$ Zob. Е. Никольский, Взгляды Всеволода и Владимира Соловьевых на парафилософское и литературное наследие Елены Блаватской, „Социально-политические науки” 2011, nr 1, ss. $99-101$.

${ }^{14}$ Chodzi też o hasła encyklopedyczne obecne w Słowniku filozoficznym Sołowjowa, poświęcone gnozie, kabale i podobnym tematom. Tematy ezoteryczne są też obecne w innych dziełach rosyjskiego myśliciela. Interesował się także parapsychologią i pisał na ten temat, co jest zgodne z opcją badawczą Towarzystwa Teozoficznego Heleny Bławatskiej.

${ }^{15}$ Zob. T. Klimowicz, Poszukujacy, nawiedzeni, opętani. Z dziejów spirytyzmu i okultyzmu w literaturze rosyjskiej, Wrocław, Wydawnictwo Uniwersytetu Wrocławskiego, 1992, ss. 59-64. 
Spirytyzm jest najczęściej praktykowaną formą okultyzmu. Rosjanin poznał osobiście wiele mediów okultystycznych i uczestniczył w licznych seansach spirytystycznych, będąc także naocznym świadkiem nadnaturalnych zjawisk. To pozostawiło ślad w jego psychice i systemie nerwowym, na co zwrócił uwagę zaprzyjaźniony z Sołowjowem wybitny filozof rosyjski, książę Jewgienij Trubieckoj ${ }^{16}$.

Spirytyzm, czyli wywoływanie duchów zmarłych, który z namiętnością i bez umiaru, długo i w każdej formie uprawiał Sołowjow, nawet teozofka i spirytystka, Helena Bławatska, nazywa czarnq magia. Słusznie podkreśla, że chodzi tu o ciężki i wielki grzech nekromancji, który Biblia, a także wielu starożytnych mędrców potępia z najwyższą surowością. Przytacza nawet przykłady fizycznych zachorowań różnych osób występujących jako media. Sołowjow też chorował ciężko w tym spirytystycznym okresie ${ }^{17}$.

Sołowjow usłyszał o Bławatskiej nie później niż w 1875 roku. W tym samym czasie poznał również w Kairze wujka teozofki. Otrzymał informację o Bławatskiej od spirytysty i propagatora spirytyzmu, Aleksandra Aksakowa, który był przyjacielem rosyjskiego filozofa do końca jego życia ${ }^{18}$. Sołowjow prenumerował przez jakiś czas pismo teozoficzne „The Theosophist”, gdzie z pewnością zaznajomił się z wieloma ideami teozoficznymi, w tym z opiniami na temat spirytyzmu. Dlatego, być może, także pod wpływem Bławatskiej, a nie tylko na skutek własnego, negatywnego doświadczenia, Sołowjow stopniowo zaczął odrzucać wspomniany typ klasycznego spirytyzmu, stale jednak wierząc w możliwość kontaktu ze zmarłymi. Ponadto sądził, że doświadczenia spirytystyczne powinny być badane naukowo i wtedy mogłyby stać się podstawą jego religijnej metafizyki ${ }^{19}$.

Według Wiktorii Krawczenko spirytyzm był dla Sołowjowa przez całe życie bardzo ważny, miał istotny wpływ na jego myśl, przechodząc później także w jego zainteresowanie parapsychologią ${ }^{20}$. Nieco innego zdania jest znawca Sołowjowa, Janusz Dobieszewski, który pisze:

„Kwestia mistycyzmu w myśli Sołowjowa wiązana jest wprawdzie często z zainteresowaniami filozofa spirytyzmem, z jego jakoby dyspozycjami mediumicznymi i skłonnościami halucynacyjnymi, czego znaczenie staraliśmy się już wcześniej minimalizować,

${ }^{16}$ Zob. В. Кравченко, Владимир Соловьев и София, Москва, АГРАФ, 2006, ss. 260-262.

${ }^{17}$ Zob. S.M. Sołowjow, Życie i ewolucja twórcza Włodzimierza Sołowjowa, tłum. E. Siemaszkiewicz, Poznań, W drodze, 1986, s. 116.

${ }^{18}$ Spośród wielu znajomych Sołowjowa A. Aksakow najbardziej zbliżył się do Bławatskiej, korespondując z nią przez 10 lat. Został członkiem Towarzystwa Teozoficznego już w 1874 roku, potem jednak wystąpił zeń i zerwał kontakty z Bławatską z powodu różnic światopoglądowych, zob. T. Klimowicz, Poszukujacy, nawiedzeni, opętani..., op.cit., s. 70.

${ }^{19}$ Ten problem objaśnia W. Krawczenko, zob. В. Кравченко, Владимир Соловьев..., ор.cit., s. 236.

${ }^{20}$ Tamże, s. 214. 
wskazując na ich wymiar tymczasowy i czysto psychologiczny, pozbawiony filozoficznej kontynuacji i filozoficznej rangi w tekstach Sołowjowa, a także powołując się na liczne i przekonywające wypowiedzi krytyczne samego Sołowjowa"21.

\section{Channeling w wydaniu Bławatskiej i Sołowjowa}

Bławatska odrzuca niższe formy mediumizmu, robi to jednak po to, by skierować uwagę ku wyższym jego formom, odrzucając jednocześnie samo pojęcie mediumizmu. Chodzi jej o inne, według niej jakościowo różne doświadczenie, które dziś nazywa się channelingiem ${ }^{22}$.

W przypadku Bławatskiej chodzi o doświadczenie odnoszące się już nie do duchów zmarłych, ale do tzw. Mahatmów, czyli ,przebóstwionych” Nauczycieli Ludzkości, z którymi teozofka miała rzekomo kontakt i którzy byli jakoby także twórcami jej pism i generalnie całej nauki teozofii ${ }^{23}$. Podobnym tropem podaża stopniowo Sołowjow, który, prawdopodobnie sugerując się także opiniami Bławatskiej (którą mimo pewnej krytyki darzył szacunkiem), odrzuca mediumizm tradycyjnych seansów spirytystycznych. Nie odrzuca jednak mediumizmu pisma automatycznego, zwanego też pismem mediumicznym, które stosuje prawie do końca życia. Pismo automatyczne jest dla Sołowjowa środkiem miłosnego czy nawet erotycznego kontaktu z tzw. Sofią, czyli istotą boską lub przebóstwiona. Odpowiada to strukturze channelingu $\mathrm{w}$ rozumieniu Bławatskiej, który później będzie nazwany „modlitwą New Age", a sama teozofka zostanie uznana za prekursorkę ideologii New Age ${ }^{24}$.

Podobny zabieg stosuje Sołowjow, gdy odrzuca stopniowo kontakty ze zmarłymi, ale rozwija kontakt z pewną duchową osobą, czyli Sofią, poprzez pismo automatyczne. Praktyka mediumizmu pozostaje ta sama. Zmienia się tylko adresat. Teraz jest to boska czy przebóstwiona Sofia, którą można porównać w przebóstwionymi Mahatmami Heleny Bławatskiej czy innymi duchami-przewodnikami, które tworzyły teozofię, także po śmierci Bławatskiej, kierując doświadczeniami np. teozofki Anny Besant. Ze względu na rzekomo boską naturę Sofii, rosyjski myśliciel okazuje

${ }^{21}$ Zob. J. Dobieszewski, Włodzimierz Sołowjow. Studium osobowości filozoficznej, Warszawa, Wydawnictwo Naukowe „Scholar”, 2002, s. 102 n.

${ }^{22}$ Bławatska odrzuca stary spirytyzm, dotyczący zmarłych, by stworzyć nowy, zwany dziś channelingiem, który dotyczy bytów ,przemienionych”, bliskich boskiej doskonałości, zob. A. Posacki, Neospirytyzm i pseudopsychologie, Kraków, Wydawnictwo „M”, 2012, ss. 24-25.

${ }^{23}$ Zob. Е.П. Блаватская, Теософский словарь, tłum. А.П. Хейдок, Москва, Эксмо, 2003, ss. 332-333.

${ }^{24}$ Zob. Papieska Rada Kultury, Papieska Rada do Spraw Dialogu Międzyreligijnego, Jezus Chrystus dawcq wody żywej. Chrześcijańska refleksja na temat New Age, Kraków, Wydawnictwo „M”, 2003, ss. 116-117. 
jej prawie ślepe posłuszeństwo, którego celem jest mistyczna inicjacja, opisana przez Sołowjowa w Trzech rozmowach o wojnie, postępie $i$ historii powszechnej (Tpu paзговора о войне, прогрессе и коние всемирной истории) po swoistym nawróceniu ${ }^{25}$.

\section{Poszukiwanie wtajemniczenia przez Sołowjowa}

Sołowjow, studiując wielu okultystów, dobrze wiedział, że aby mieć duchową władzę trzeba doświadczyć inicjacji czy wtajemniczenia, za którym - jak się wydaje - całe życie tęsknił.

W istocie bowiem zarówno Bławatskiej, jak i Sołowjowowi chodziło o radykalną inicjację, wtajemniczenie na głębokim poziomie, swoiste przebóstwienie (czy raczej ubóstwienie), które zaowocuje nadzwyczajnym poznaniem i parapsychiczną mocą. Szło także o gnozę i magię, nazywaną przez Sołowjowa mistycyzmem i teurgią. Chciał umiejscowić swoje doświadczenie w ramach jakiejś starożytnej czy archaicznej tradycji ${ }^{26}$.

Jak się okazuje, podobna inicjacja była także wolą tajemniczych przewodników. Nie tylko zachęcali do niej, ale wymagali ślepego posłuszeństwa w realizacji tego celu. Dla jego osiagnięcia Sołowjow miał swojego ducha przewodnika, tak jak Bławatska czy Besant, i starał się być mu posłuszny. Sam też zresztą ów nieznany i nigdy nierozpoznany duch, przedstawiający się jako Sofia (czasami występował pod postacią węża czy wprost podpisywał się jako „czort”), wzywał Sołowjowa do wyłącznego, ślepego posłuszeństwa.

Sołowjow poszukiwał więc wtajemniczenia w pełną mocy boskość. Książki, które studiował w Londynie to głównie opisy gnostyckich, hermetycznych, kabalistycznych, różokrzyżowych, masońskich inicjacji i rytuałów wtajemniczenia. Sołowjow zachwyca się mądrością myślicieli i praktyków ezoteryzmu i okultyzmu, ale poszukuje też realnej przemiany i mocy. W tym celu pojechał do Egiptu, gdzie „duchy” objawiły mu istnienie kabalistycznej tajnej organizacji, obiecując go doń wprowadzić27.

W XIX wieku europejscy okultyści masowo podróżowali do Egiptu. W poszukiwaniu wtajemniczenia jeździli tam Gerard de Nerval i H. Bławatska (lata 60.). W Egipcie był także Aleister Crowley, twórca zachodniego okultyzmu i satanizmu ${ }^{28}$.

${ }^{25}$ Zob. J. Krasicki, Bóg, człowiek i zło. Studium filozofii Włodzimierza Sołowjowa, Wrocław, Fundacja na Rzecz Nauki Polskiej, Wydawnictwo Uniwersytetu Wrocławskiego, 2003, ss. 325-327.

${ }^{26}$ Pisze o tym przekonująco W. Krawczenko, zob. В. Кравченко, Владимир Соловьев..., ор.cit., ss. $142-143$.

${ }^{27}$ Ibidem, s. 224.

${ }^{28}$ Istnieją porównania Sołowjowa do Crowleya. 
Wtajemniczenie czy inicjacja to także kluczowe doświadczenia masonerii. Dla ideologii masońskiej Egipt był zawsze kolebką wtajemniczeń2 ${ }^{29}$.

\section{Podobieństwo źródeł i autorytetów}

Podobieństwo Sołowjowa do Bławatskiej i innych okultystów występuje na gruncie teorii i praktyki. Uderza korzystanie z tych samych źródeł i uznanie tych samych okultystycznych autorytetów. Sołowjow zachwyca się Paracelsusem, Boehmem czy Swedenborgiem i wieloma innymi ezoterykami w taki sam sposób, jak Bławatska. Dlatego ktoś, kto czyta Sołowjowa łatwo może zainteresować się Heleną Bławatską czy Rudolfem Steinerem (twórcą antropozofii), który także pisał o Sołowjowie.

W rękopisach Sołowjowa spotykamy spis nazwisk autorów, których dzieła chciał przebadać. Chodzi tu o wielu znanych filozofów i ezoteryków. Są to np. Raymond Lull, Roger Bacon, Paracelsus, Agrippa a Nettesheinm, Arnaud de Villeneuve, Samuel Norton, Barneud, Becher, Clopinel, Borrichius, Valentin Weigel, Nicolas Flamel, Robert Fudd, Michel Maier i wielu innych ${ }^{30}$. Wiele z tych nazwisk odnajdujemy w Stowniku teozoficznym Bławatskiej.

\section{Krytyka teozofii Bławatskiej w filozofii rosyjskiej}

Dla rosyjskiej filozofii religijnej właściwe jest odrzucenie doktryny teozoficznej Bławatskiej. Jak pisze teolog prawosławny, Andriej Kurajew, rosyjscy filozofowie pierwszej wielkości - Sergiusz Bułhakow, Siemion Frank, Mikołaj Łosski, Mikołaj Bierdiajew, Lew Karsawin, Wasilij Zieńkowski, Gieorgij Florowski, Paweł Florenski, Borys Wyszesławcew, Aleksiej Łosiew i wielu innych - bardzo krytykowali teozofię Bławatskiej i antropozofię Steinera. Ich wypowiedzi podano w podrozdziale ,Ignoranci" o teozofii (,,Невежды”" о теософии) w drugim tomie książki Satanizm dla inteligencji (Сатанизм для интеллигенции) $)^{31}$.

Jednym z pierwszych obrońców prawosławia przeciw teozofii został rosyjski powieściopisarz Wsiewołod Sołowjow, który osobiście znał Helenę Bławatską i opisał krytycznie liczne spotkania z nią w książce Współczesna kapłanka Izydy (Современная жрица Изиды) $)^{32}$.

\footnotetext{
${ }^{29}$ Zob. N. Wójtowicz, Masoneria, op.cit.; В. Кравченко, Владимир Соловьев..., ор.cit., s. 120.

${ }^{30}$ Zob. К. Ю. Бурмистров, Владимир Соловьев и европейский эзотеризм..., ор.cit, s. 55.

${ }^{31}$ Zob. А. Кураев, Сатанизм для интеллигенции ..., ор.cit., ss. 295-322.

${ }^{32}$ Zob. T. Klimowicz, Poszukujacy, nawiedzeni, opętani..., op.cit., s. 34.
} 
Dla wspomnianych filozofów uderzająca jest niewiarygodność argumentów filozoficznych ze strony teozofii. Dlatego właśnie większość filozofów rosyjskich jest krytyczna wobec teozofii Bławatskiej. Szczególnie Bierdiajew i Sołowjow, których negatywna ocena jest przede wszystkim natury filozoficznej i metodologicznej. Bierdiajew zarzuca Bławatskiej i jej teozofii błędy naturalizmu i ewolucjonizmu, racjonalizmu i materializmu. Jest to swoista materializacja duchowości, pozbawiająca człowieka wolności ${ }^{33}$. Sołowjow z kolei postrzega koncepcję Bławatskiej jako antyreligijna, antyfilozoficzną i antynaukową. Istnieje bowiem także obiektywnie stwierdzona przez innych badaczy niewiarygodność twierdzeń naukowych w sferze dowodów empirycznych, wbrew teozoficznym wizjom ${ }^{34}$.

Sołowjow osądza negatywnie główne dzieła Bławatskiej, takie jak Izyda odstonięta (Isis Unveiled: A Master-Key to the Mysteries of Ancient and Modern Science and Theology) ${ }^{35}$, Tajna doktryna (The Secret Doctrine, the Synthesis of Science, Religion and Philosophy) czy Klucz do teozofii (The Key to Theosophy), zarzucając im kompletny brak systematyczności i metodologicznej konsekwencji. Odnotowuje przy tym sprzeczności bez próby ich pogodzenia. Twierdzi nawet, że tak bezładnej książki jak Izyda odsłonięta nigdy nie czytał. Dostrzega eklektyzm i kompilację, stwierdza fałsz tej ideologii jako całości, ale też zwraca uwagę na duże oczytanie autorki ${ }^{36}$. Krytyka Sołowjowa jest jednak nie zawsze konsekwentna.

\section{Dwuznaczność krytyki ideologii Bławatskiej ze strony Sołowjowa}

Antypersonalizm wspólnej dla teozofii i masonerii (i wielu innych teorii ezoterycznych, jak antropozofia, Agni Joga i New Age) koncepcji reinkarnacji zauważa Bierdiajew, ale nie Sołowjow, który - za kabałą - nie wykluczał wiarygodności teorii reinkarnacji ${ }^{37}$. W tym miejscu znowu Sołowjow zbliża się do Bławatskiej.

Rosyjski filozof odkrył częściowo „błąd antropologiczny” u Bławatskiej, wskazując na brak podstawy antropologicznej dla ludzkiego ,ja”, które rozmywa się w systemie kosmocentrycznym. Wskazał też na niestosowność czy wręcz sprzeczność samego pojęcia „teozofii” w systemie, który nie przyjmuje Boga osobowego, a wszelkie

${ }^{33}$ Zob. A. Кураев, Сатанизм для интеллигенции ..., op.cit., ss. 302-303.

${ }^{34}$ Widać to u Bławatskiej i Steinera, gdzie mowa jest o krainach geograficznych czy ludach, których istnienia nie potwierdzają badania naukowe. Na ten temat więcej zob. Л.И. Фесенкова, Сииентизация эзотерики и псевдонаука, „Социологические исследования” 2004, nr 2, ss. 92-98.

${ }^{35}$ Część pism Bławatskiej ukazywała się najpierw w języku angielskim, a dopiero potem tłumaczono je na język rosyjski.

${ }^{36}$ Zob. Ibidem, ss. 297-298.

${ }^{37}$ Zob. M. Bierdiajew, Filozofia wolności, tłum. E. Matuszczyk, Białystok, Orthdruk, 1995, s. 173. 
bóstwa przewijające się w teozofii sytuuje niżej od człowieka. Jest to więc raczej przejaw człekobóstwa ${ }^{38}$. Jednakże akceptacja przez Sołowjowa siedmiostopniowej, okultystycznej struktury człowieka, którą odnajduje u Bławatskiej, także nie odpowiada wizji antropologii chrześcijańskiej, którą rzekomo popierał Sołowjow ${ }^{39}$.

Interesujące jest natomiast, że Sołowjowa nie niepokoił problem lucyferyzmu w teozofii Bławatskiej (inicjacja lucyferyczna, typowa dla całej tradycji teozoficznej), skoro początkowo odrzucał istnienie diabła i piekła ${ }^{40}$. Wiązało się to oczywiście z fundamentalnym problemem zła (z punktu widzenia teologii grzechu i szatana, a także piekła), jego przedefiniowaniem, a nawet eliminacją (pisał o tym wnikliwie J. Krasicki), które występuje zarówno u Bławatskiej, jak i Sołowjowa ${ }^{41}$. W tym aspekcie Sołowjow wyraźnie upodabnia się do Bławatskiej. Widoczne jest to szczególnie w ostatnim okresie życia rosyjskiego filozofa, kiedy napisał Trzy rozmowy i Opowieść o Antychryście (Краткая повесть об Антихристе), będące - według wielu badaczy - przejawem pewnego otrzeźwienia w kwestii ignorowania przez niego Tajemnicy Zła ${ }^{42}$.

\section{Problem zła oraz Szatana u Sołowjowa i Bławatskiej}

Specyficznie postawiony problem zła występuje nie tylko u Schellinga czy Hegla, ale także całkiem podobnie u okultystów, Eliphasa Leviego i Heleny Bławatskiej ${ }^{43}$. Podobnie jest w każdym ezoteryzmie, a także w ideologii masońskiej (na którą otwierał się Sołowjow, tak jak i na teorie wymienionych wyżej filozofów i okultystów), gdzie dobro i zło stawia się na równi ${ }^{44}$. Jest to swoisty monodualizm, o czym świadczą symbole teozofii i masonerii ${ }^{45}$. Odpowiada on ideologii panteizmu, który widnieje - według opinii wielu znawców - także u Sołowjowa ${ }^{46}$.

${ }^{38}$ Zob. А. Кураев, Сатанизм для интеллигенции ..., ор.cit., ss. 298-300.

${ }^{39}$ Zob. В. Кравченко, Владимир Соловьев..., ор.cit., s. 218. Więcej na temat antropologii H. Bławatskiej zob. B. Grom, Ezoteryzm - nowa nadzieja?, tłum. U. Poprawska, Kraków, Wydawnictwo WAM, 2006, ss. 42-45.

${ }^{40}$ Zob. S.M. Sołowjow, Życie i ewolucja twórcza ..., op.cit., s. 155.

${ }^{41}$ Zob. J. Krasicki, Bóg, człowiek $i$ zło..., op.cit., ss. 310-311.

${ }^{42}$ Tamże, ss. 312-320.

${ }^{43}$ To podobieństwo wymaga oczywiście dodatkowych dowodów i badań. Jednakże takie podobieństwo tychże filozofów i okultystów, wynika z ich wspólnego nachylenia gnostyckiego.

${ }^{44}$ Zob. A. Кураев, Сатанизм для интеллигеници ..., ор.cit., s. 146.

${ }^{45}$ Bławatska powołuje się tu na rzekomo kabalistyczny aksjomat: „Demon est deus inversus”, zob. Е. Блаватская, Теософский словарь, ор.cit., s. 8.

${ }^{46}$ Zob. П.П. Гайденко, Владимир Соловьев и философия Серебряного века, Москва, Прогресс-Традиция, 2001, s. 400n. Wnikliwie o problemie panteizmu u Sołowjowa pisze też Janusz Dobieszewski, zob. Idem, Włodzimierz Sołowjow. Studium..., op.cit., ss. 253-254. 
Jan Krasicki, który ze wszystkich znanych mi badaczy najpełniej pisze o pojęciu zła u Sołowjowa (choć przy tym pomniejsza temat okultyzmu), słusznie zwraca uwagę na watki demonologiczne pozwalające wyjaśnić zagadkę Sołowjowa, przypuszczając zarazem, że kluczowe znaczenie dla tegoż wyjaśnienia może mieć figura Szatana $^{47}$. Dostrzega zarazem, że Sołowjow pomija istnienie Tajemnicy Zła, mysterium iniquitatis ${ }^{48}$.

Z gnozą zwykle związany jest temat satanizmu i lucyferyzmu. Młody Sołowjow włącza figurę Szatana we własną kosmologię, Bławatska uważa Lucyfera za boga kosmosu ${ }^{49}$. Widzimy tu pewne analogie. Podobnie pozytywny stosunek do Szatana, identyfikowanego z romantycznym buntownikiem, miał także symbolizm rosyjski, co dopełnia dosyć powszechny obraz „bonizacji” zła w kulturze rosyjskiej $^{50}$.

Nie chodzi jednak tylko o filozoficzny i teologiczny problem zła (pod wpływem gnostycyzmu, kabały czy Schellinga, będący skutkiem tych ezoterycznych koncepcji), ale teoretyczny i praktyczny stosunek do Szatana, co w konsekwencji określa także optymistyczny i zarazem naiwny stosunek do mediumizmu.

Sołowjow jako młody filozof pisał, że nie wierzy w Szatana jako osobowe zło. Uczynił bowiem za Schellingiem zło integralną częścią kosmosu, a nawet Boga. Tego rodzaju ontologizacja zła, a także ontologizacja Szatana raczej jako bezosobowej struktury kosmicznej, a nie osoby, która inteligentnie i strategicznie zwodzi człowieka, odsuwając go od Boga, powoduje optymistyczny, a nawet beztroski stosunek również wobec wszelkich praktyk duchowych. Ontologizacja zła osłabia jego moralną ocenę, bo zło tak pojęte staje się czymś koniecznym. Pojmowane jest bowiem jako niezbędna część Boga i kosmosu ${ }^{51}$.

Jak zauważa Janusz Dobieszewski, w pracach poświęconych Sofii, Sołowjow osłabi i zmieni pozycję Szatana w swojej kosmologii, usunie pojęcie Demiurga i będzie unikał dwuznaczności związanych z innymi pojęciami, a terminy gnostyckie i kabalistyczne ustąpią miejsca pojęciom teologii chrześcijańskiej ${ }^{52}$.

${ }^{47}$ Zob. J. Krasicki, Bóg, czlowiek i zło..., op.cit., ss. 335-338.

${ }^{48}$ Ibidem, ss. 309-311.

${ }^{49}$ Zob. A. Кураев, Сатанизм для интеллигенции ..., op.cit., ss. 148-149.

${ }^{50}$ Zob. Л. Попова, „Демоническое” в художественной культуре Серебряного века: культурфилософские аспекты. Автореферат диссертаиии на соискание ученой степени кандидата культурологии, Москва, Государственный институт искусствознания Министерства культуры Российской Федерации, 2014.

${ }^{51}$ Zob. S.M. Sołowjow, Życie i ewolucja twórcza ..., op.cit., ss. 133-135.

${ }^{52}$ Zob. J. Dobieszewski, Włodzimierz Sołowjow. Studium..., op.cit., s. 299. 


\section{Problem piekła i niebezpieczny mediumizm Sołowjowa}

Osobny temat dotyczy nie tylko Szatana, ale też idei piekła w teorii i praktyce duchowej Sołowjowa. Odrzucał piekło i diabły, by stworzyć religię uniwersalną̧53. Rosyjski filozof prezentuje tu spirytystyczny pogląd na los nieśmiertelnej duszy w pośmiertnym świecie, gdzie - według Emanuela Swedenborga, który miał na niego wpływ - nie było piekła. Tu istotnie zbliża się on do Bławatskiej (zwolenniczki spirytysty Allana Kardeca, głosiciela reinkarnacji). W kwestiach eschatologicznych Sołowjow otwierał się też na wizję apokatastazy, zakładającej zbawienie Szatana ${ }^{54}$. Koresponduje to ostatecznie z lucyferyzmem Bławatskiej ${ }^{55}$.

Wiktoria Krawczenko twierdzi, że Sołowjow także w wymiarze praktycznym zanurza się poznawczo w „głębiny Szatana" ${ }^{56}$. Andriej Biełyj, poeta i symbolista rosyjski, potwierdza, że Sołowjow miał ustawiczne widzenia diabła w różnych postaciach, o czym słyszał od samego Sołowjowa. Wybitny filozof Wasilij Rozanow widział w Sołowjowie wcielenie ,demonicznego pierwiastka”. Natomiast bratanek Sołowjowa, Sergiusz, twierdzi, że był on opętany diabolicznymi wizjami i to doświadczenie duchowe nie było zgodne z jego optymistycznymi filozoficznymi teoriami ${ }^{57}$.

Czy chodzi tu o „demoniczną mistykę”, której opis znajdziemy w Słowniku filozoficznym Władimira Sołowjowa ${ }^{58}$ (Философский словарь Владимира Соловьева)? Wielu było o tym przekonanych. Badacz twórczości Sołowjowa, Konstantin Moczulski, twierdzi, że u Rosjanina widzimy nie tylko doświadczenie mistyczne, ale i okultystyczne ${ }^{59}$. Bierdiajew mówi w podobnym kontekście o Sołowjowie „dziennym" i ,nocnym"60. Widoczne było w nim istotne rozdwojenie pomiędzy mistyką sofijną a mistyką demoniczną. Najbliżsi uważali Sołowjowa za silne medium ${ }^{61}$. Krawczenko uważa, że był i pozostał do końca „pasywnym medium”62. W Egipcie

\footnotetext{
${ }^{53}$ Zob. Г.В. Флоровский, Пути русского богословия, (reprint wydania Париж 1937), Вильнюс, Литовская православная епархия, 1991, s. 556.

${ }^{54}$ Sołowjow wycofa się z idei apokatastazy w 1885 r., zob. G. Przebinda, Włodzimierz Sołowjow wobec historii, Kraków, Arka, 1992, s. 42.

${ }^{55}$ Podobny lucyferyzm o wyraźnie kultycznym charakterze występuje w koncepcji teozofa A.K. Klizowskiego, ucznia Bławatskiej i zwolennika Rerichów, zob. А. Клизовский, Основы миропонимания Новой Эпохи, Минск, Звезды Гор, 2008, s. 723.

${ }^{56}$ В. Кравченко, Владимир Соловьев..., ор.cit., s. 141.

${ }^{57}$ Zob. S.M. Sołowjow, Życie i ewolucja twórcza ..., op.cit., s. 155.

${ }^{58}$ Философский словарь Владимира Соловьева, zebrał i wstępem opatrzył Г.В. Беляев, Ростовна-Дону, Феникс, 2000.

${ }_{59}$ Zob. В. Кравченко, Владимир Соловьев..., ор.cit., s. 257.

${ }^{60}$ Zob. G. Przebinda, Włodzimierz Sołowjow..., op.cit., s. 24.

${ }^{61}$ Zob. В. Кравченко, Владимир Соловьев..., ор.cit., ss. 257-264.

${ }^{62}$ Ibidem, s. 232.
} 
Sołowjow spotkał Szatana w swoistej „satanofanii” - i to go dopiero otrzeźwiło i doprowadziło do przeżycia oświecenia i przemiany ${ }^{63}$.

\section{Podsumowanie}

\section{Istotne podobieństwa teoretyczne}

U Sołowjowa mamy do czynienia z próbą syntezy mistycyzmu (religii), filozofii i nauki, u Bławatskiej było podobnie. Czy te podobieństwa są rzeczywiste, czy różnice są tu radykalne? Odpowiedzi na te pytania wymagają dalszych badań. Być może odmienności nie są tak wielkie, gdyż synteza Sołowjowa nie wydaje się doskonała, jest także bliska gnozie, co stwierdził między innymi Lew Szestow ${ }^{64}$.

W Słowniku filozoficznym Władimira Sołowjowa znajdujemy erudycyjne hasło, gdzie mistyką - realną mistyką - nazywa on w istocie wszelkie formy ezoteryzmu i okultyzmu. Sołowjow mówi, że tego rodzaju mistyka może być boska, naturalna i demoniczna. Twierdzi też błędnie, że jest to podział chrześcijański. Tak rozumianą „mistykę” oddziela od „mistycyzmu”, który polega na wewnętrznym i bezpośrednim obcowaniu z Absolutem. Tego rodzaju mistycyzm może być nazwany mistyczną teologią, mistyczną filozofią lub teozofią ${ }^{65}$. Bezpośredni kontakt u Sołowjowa ma charakter mistyczny. Jest to bezpośredni kontakt jakoby z osobowym Absolutem, a u Bławatskiej, bezpośredni kontakt z różnymi bytami kosmicznymi, i to jest okultystyczny mediumizm ${ }^{66}$. Trudno tu odróżnić mistycyzm od mediumizmu, tym bardziej że Sołowjow mediumizm okultystyczny nazywa mistyką i odnosi się do niej pozytywnie, co dodatkowo sprzyja zamazywaniu granic między nimi ${ }^{67}$.

Podobnie jak dla Bławatskiej, wzorem dla mistycyzmu Sołowjowa są gnostycyzujący myśliciele i mistycy, tacy jak Boehme i Swedenborg ${ }^{68}$. Istnieje więc wspólnota idei, ale także wspólnota osób jako autorytetów. Trzeba przyznać, że niejednokrotnie Sołowjow krytykuje Bławatską, ale w mało istotnych aspektach, głównie metodologicznych, a nie w kwestiach merytorycznych. Wyrażając do niej wielki szacunek, nazywa jej ideologię „neobuddyzmem”, nie dostrzega zaś niebezpieczeństwa mediumizmu, okultyzmu czy lucyferyzmu, obecnego expressis verbis u Bławatskiej.

${ }^{63}$ Zob. G. Przebinda, Włodzimierz Solowjow.... op.cit., ss.193-195.

${ }^{64}$ Zob. tamże, ss. 212-213.

${ }^{65}$ Zob. Философский словарь Владимира Соловьева, ..., op. cit., ss. 287-291.

${ }^{66} \mathrm{O}$ realnej dwuznaczności filozofii mistycyzmu Sołowjowa pisze J. Dobieszewski, zob. Idem, Włodzimierz Sołowjow. Studium... op.cit., s. 119.

${ }^{67}$ Zob. Философский словарь Владимира Соловьева..., op. cit., ss. 287-291.

${ }^{68}$ Zob. Теософский словарь Е.П. Блаватской, [w:] http://www.edudic.ru/tsb/ [dostęp: 15.03.2021]. 
Wynika to także z faktu, że obydwoje nie uznawali autorytetu ortodoksji chrześcijańskiej, ale raczej zgodnie reprezentowali to, co można nazwać „ezoterycznym chrześcijaństwem" $"$.

Sprawa dotyczy więc nie tylko podobieństwa formy, ale i treści, czego Sołowjow nie widział lub nie chciał widzieć. Podobieństw koncepcji Sołowjowa do teorii Bławatskiej jest może nawet więcej niż różnic, ale to jest temat na osobną rozprawę. Analogie merytoryczne w teozofiach Sołowjowa i Bławatskiej sygnalizuje niewielu rosyjskich badaczy.

\section{Istotne podobieństwa praktyk duchowych}

Sołowjow od początku swojej aktywności twórczej zna Bławatską i jej pisma teozoficzne. Do końca zachowuje szacunek do niej (Wstęp do Trzech rozmów).

Negatywne sądy Bławatskiej odnośnie do mediumizmu, podobnie jak sądy Heleny Rerich, były częściowo słuszne, gdy określały spirytystyczny mediumizm jako szkodliwy dla ciała i duszy, szkodliwy moralnie i duchowo. Możliwe, że Sołowjow znał te opinie Bławatskiej ${ }^{70}$. Jednak Bławatska i Rerich uprawiały mediumizm innego rodzaju, który uważały za słuszny. Można go nazwać channelingiem ${ }^{71}$. Podobnie Sołowjow zrezygnował ze spirytyzmu, ale nie z mediumizmu. Uczynił to, co często czynią okultyści: zrezygnował z czarnej magii, ale nie z tzw. białej magii. Pisząc o szkodliwości spirytyzmu Bławatska i Sołowjow mieli na myśli klasyczny spirytyzm, czyli kontakty z duchami zmarłych (nekromancję), a nie wyższy spirytyzm (channeling), który Sołowjow określa jako mistykę. Sołowjow stosował podczas seansów pismo automatyczne ${ }^{72}$. Podobnie czyniła Helena Rerich, potępiając niski mediumizm, wykorzystywała pismo automatyczne w kontakcie z Mahatmami ${ }^{73}$.

Dla Sołowjowa była to Sofia (wpływy gnostycko-kabalistyczne), a dla Bławatskiej - przebóstwieni Mahatmowie (wpływy hinduizmu i buddyzmu). W obydwu przypadkach status ontologiczny tych nieśmiertelnych rzekomo istot zbliżał się do boskiego. Jednocześnie status ten był niejasny i dlatego niebezpieczny. Duchy zmar-

${ }^{69}$ Chrześcijaństwo Sołowjowa to osobny temat. Był z pewnością chrześcijaninem (w przeciwieństwie do Bławatskiej), ale o nachyleniu gnostyckim (opinia W. Krawczenko). Pozostawiam tę kwestię otwarta, zob. А. Безант, Эзотерическое христианство, Москва, АРТ, 1991.

${ }^{70}$ Szczególnie od A. Aksakowa.

${ }^{71}$ „Channeling” - „kanałowanie” psychiczne; media twierdzą, że działają jako kanały, pozwalające na przepływ informacji pochodzących od innych istot, zwykle bezcielesnych jednostek, żyjących na wyższych poziomach. Channeling łączy istoty tak zróżnicowane jak: wywyższeni mistrzowie, aniołowie, bogowie, jednostki grupowe, duch natury i Wyższe Ja”, zob. Papieska Rada Kultury, Papieska Rada do Spraw Dialogu Międzyreligijnego, Jezus Chrystus dawca wody żywej..., op.cit., s. 104.

${ }^{72}$ Tamże, s. 70.

${ }^{73}$ Zob. А. Кураев, Сатанизм для интеллигенции ..., ор.cit., ss. 266-269. 
łych zostały zastapione przez byty nadludzkie, przemienione, nawet jeśli były one kiedyś ludźmi. Uważano, że bytom tym - z racji ich wyższości - jesteśmy obowiązani posłuszeństwo. Ale ich status był niemożliwy do zewnętrznej weryfikacji.

\section{Istotne wyzwania metodologiczne}

Wielkim wyzwaniem badawczym jest ustalenie podobieństwa mediumizmu okultystycznego do pewnych epistemologicznych trendów filozofii rosyjskiej, która zresztą generalnie nachyla się ku szeroko rozumianej gnozie ${ }^{74}$. Chodzi na przykład o intuicjonizm rosyjski czy też otwarte doświadczenie religijne (często preferowane w myśli rosyjskiej), ściśle połączone z krytyką zachodniego myślenia dyskursywnego. To wszystko sprzyja pomieszaniu pojęć i tworzy matryce, które przygotowują określone procesy kulturowe, choćby tylko na powierzchni kultury masowej.

W nastawionej mistycznie filozofii rosyjskiej istnieje epistemologiczne i metodologiczne podobieństwo z ezoteryzmem czy okultyzmem. Chodzi tu między innymi o tak zwany mistycyzm Sołowjowa, także ten teoretyczny, intuicjonizm rosyjski M. Łosskiego, otwartego na ideę reinkarnacji, intuicjonizm S. Franka, podejrzewanego przez niektórych filozofów o panteizm, doświadczenie gnostyckie M. Bierdiajewa, połączone z krytyką zachodniego rozumu.

Najbardziej niebezpiecznym kluczem jest tu tzw. bezpośrednie poznanie Boga czy bóstwa. Rodzi się pytanie: czy to jest mistyka czy może mediumizm? Doświadczenie transcendencji czy tylko immanencji? Sołowjow mediumizm okultystyczny zalicza do mistyki, ale dumnie odróżnia mediumiczną ,mistykę” - nie potępiając jej w żaden sposób - od filozoficznego „mistycyzmu”, który jednak także może sprzyjać mediumizmowi, ze względu na brak zewnętrznych i obiektywnych kryteriów weryfikacji, a także z racji „,bezprzedmiotowego” charakteru ${ }^{75}$.

Zagrożenie wynika także z odrzucania w myśli rosyjskiej rozumu dyskursywnego i logiki (w tym scholastyki), preferowania otwartego poznania symbolicznego, tak ważnego dla ezoterycznego światopoglądu. Łączyło się to często z odrzucaniem zasady niesprzeczności, na rzecz antynomii czy dialektyki, co widać na przykładzie koncepcji wybitnego myśliciela Pawła Florenskiego, także uwikłanego mocno w okultyzm $^{76}$. Gnoza i kabała, którą cenili Florenski, Bierdiajew, Sołowjow i Bułgakow to ta sama (lub też wspólna czy pokrewna) matryca ideologiczna, która była ważna dla Bławatskiej i Steinera.

${ }^{74}$ Pisał o tym wnikliwie S. Mazurek, zob. przypis 4.

${ }^{75}$ J. Dobieszewski analizuje problem mistycyzmu Sołowjowa, traktując go jako mistycyzm intelektualny, różny od uczuciowego, co zasadniczo eliminuje problem mediumizmu, zob. J. Dobieszewski, Włodzimierz Sołowjow. Studium ..., op.cit., ss. 102-104.

${ }^{76}$ Zob. P. Florenski, Filar i podpora prawdy. Próba teocydei prawosławnej $w$ dwunastu listach, tłum. J. Chmielewski, Warszawa, Wydawnictwo KR, 2009, ss. 590-591. 
Sołowjow i jego dyskusyjny panenteizm (czy może panteizm) miał wpływ na filozofię rosyjską (filozofia Wszechjedności). Bławatska i Steiner oddziaływali z kolei na literaturę i sztukę rosyjską poprzez idee kosmocentrycznego monizmu, monodualizmu i panteizmu. Tu panenteizm, tam panteizm - granice są bardzo płynne. Zwłaszcza jeśli w filozofii rosyjskiej dominuje intuicjonizm, mistycyzm czy też bliżej nieokreślone doświadczenie religijne, a w teozofii i antropozofii - okultystyczny mediumizm (także nazywany intuicją lub jasnowidzeniem). Trudno określić kryteria prawdziwości i granice. Sprawa jednak wymaga jeszcze wielu dogłębnych badań.

\section{Literatura}

Bierdiajew M., Filozofia wolności, thum. E. Matuszczyk, Białystok, Orthdruk, 1995. Dobieszewski J., Włodzimierz Sołowjow. Studium osobowości filozoficznej, Warszawa, Wydawnictwo Naukowe Scholar, 2002, 482 ss.

Florenski, P. Filar i podpora prawdy. Próba teocydei prawostawnej w dwunastu listach, tłum. J. Chmielewski, Warszawa, Wydawnictwo KR, 2009, 672 ss.

Grom B., Ezoteryzm - nowa nadzieja?, tłum. U. Poprawska, Kraków, Wydawnictwo WAM, 2006, 203 ss.

Klimowicz T., Poszukujący, nawiedzeni, opętani. Z dziejów spirytyzmu i okultyzmu w literaturze rosyjskiej, Wrocław, Wydawnictwo Uniwersytetu Wrocławskiego 1992, 114 ss.

Krasicki J., Bóg, człowiek i zło. Studium filozofii Włodzimierza Sołowjowa, Wrocław, Fundacja na Rzecz Nauki Polskiej, Wydawnictwo Uniwersytetu Wrocławskiego, 2003, 428 ss.

Mazurek S., Dziedzictwo gnozy w rosyjskiej filozofii religijnej, [w:] http://www.ahf. ifispan.pl/pl/58-mazurek-gnoza [dostęp: 20.05.2021].

Papieska Rada Kultury, Papieska Rada do Spraw Dialogu Międzyreligijnego, Jezus

Chrystus dawca wody żywej. Chrześcijańska refleksja na temat New Age, Kraków Wydawnictwo „M”, 2003, 127 ss.

Przebinda G., Włodzimierz Sołowjow wobec historii, Kraków, Arka, 1992, 245 ss.

Posacki A., Ezoteryzm i okultyzm - formy dawne i nowe. Aspekty filozoficzno-teologiczne i praktyczno-duszpasterskie, Radom, Polskie Wydawnictwo Encyklopedyczne, 2009, 520 ss.

Posacki A., Neospirytyzm i pseudopsychologie, Kraków, Wydawnictwo „M”, 2012, 482 ss.

Sołowjow S. M., Życie i ewolucja twórcza Włodzimierza Sołowjowa, thum. E. Siemaszkiewicz, Poznań, W drodze, 1986, 395 ss.

Wójtowicz N., Masoneria, Warszawa, Verbinum, 2006, 468 ss. 
Безант А., Эзотерическое христианство, Москва, АРТ, 1991, 193 ss.

Блаватская Е.П., Теософский Словарь, tłum. А.П. Хейдока, Москва, Эксмо-пресс, 2003, 634 ss.

Бонецкая Н.К., Русская софиология и антропософия, [w:] http://bdn-steiner.ru/ modules.php?name=Books\&go=page \&pid=302 [dostęp: 15.05.2021].

Бурмистров К.Ю., Владимир Соловьев и европейский эзотеризм: проблема источников, „Соловьевские исследования” 2016, nr 2(50), ss. 47-65.

Гайденко П.П., Владимир Соловьев и философия Серебряного века, Москва, Прогресс-Традиция, 2001, 472 ss.

Клизовский А., Основы миропонимания Новой Эпохи, Минск, Звезды Гор, 2008, 800 ss.

Кравченко В., Владимир Соловьев и София, Москва, АГРАФ, 2006, 381 ss.

Куляница Д.С., Теософия Е.П. Блаватской и русская литература и искусство (конеи XIX-середина XX века), [w:] Современное миропонимание: духовнье аспекты развития культуры. Материаль ежегодной научно-практической конференции „Е.П. Блаватская и современность”, red. Ю.А. Шабанова, А.С. Пригунов, И.В. Павленко, Днепропетровск, Национальный горный университет, 2013, ss. 15-33.

Кураев А., Сатанизм для интеллигенции (О Рерихах и Православии в двух томах). Т 2, Христианство без оккультизма, Москва, Издательство Московского Подворья Свято-Троицкой Сергиевой Лавры, 2006, 429 ss.

Никольский Е., Взгляды Всеволода и Владимира Соловьевых на парафилософское и литературное наследие Елены Блаватской, „Социально-политические науки" 2011, nr 1, ss. 99-101.

Попова Л., „Демоническое” в художественной культуре Серебряного века: культурфилософские аспектьл. Автореферат диссертации на соискание ученой степени кандидата культурологии, Москва, Государственный институт искусствознания Министерства культуры Российской Федерации, 2014, 26 ss.

Фесенкова Л.И., Сциентизаџия эзотерики и псевдонаука, „Социологические исследования" 2004, nr 2, ss. 92-98.

Философский Словарь Владимира Соловьева, zebr. Г.В. Беляев, Ростов-на-Дону, Феникс, 2000, 464 ss.

Флоровский Г. В., Пути русского богословия, (reprint wydania Париж 1937), Вильнюс, Литовская православная епархия, 1991, 599 ss. 


\section{References}

Beliaev G. (Ed.), Filosofskii slovar' Vladimira Solov'eva [Vladimir Solovyov's Philosophical Dictionary], Rostov-on-Don, Feniks Publ., 2000, 464 pp.

Bezant A., Ezotericheskoe khristianstvo [Esoteric Christianity], trans. E. Pisareva, Moscow, ART. Publ., 1991, 193 pp.

Bierdiajew M., Filozofia wolności [Philosophy of Freedom], trans. E. Matuszczyk, Białystok, Orthdruk, 1995.

Blavatsky H, Teosofskii slovar' [Theosophical Dictionary], trans. A. P. Kheidok, Moscow, Eksmo-press, 2001, 634 pp.

Bonetskaia N. K., Russkaia sofiologiia i antroposofiia, [Russian Sopheology and Anthroposophy]. Available at: http://bdn-steiner.ru/modules.php?name=Books $\&$ go=page\&pid=302 [accessed: 15.05.2021] .

Burmistrov K. Iu., Vladimir Solov'ev i evropeiskii ezoterizm: problema istochnikov [Vladimir Solovyov and European Esotericism: Problem of Sources], "Solovyov Studies" 2016, no. 2 (50), 47-65 pp.

Dobieszewski J., Włodzimierz Sołowjow. Studium osobowości filozoficznej [Vladimir

Solovyov. Study of Philosophical Identity], Warszawa, Wydawnictwo Naukowe Scholar, 2002, 482 pp.

Fesenkova L.I., Stsientizatsiia ezoteriki i psevdonauka [Scientification of Esotericism and Pseudoscience], "Sociological Studies" 2004, no. 2, pp. 92-98.

Florenski, P. Filar i podpora prawdy. Próba teocydei prawosławnej $w$ dwunastu listach, [The Pillar and Ground of the Truth: An Essay in Orthodox Theodicy in Twelve Letters], trans. J. Chmielewski, Warszawa, Wydawnictwo KR, 2009, $672 \mathrm{pp}$.

Florovskii G.V., Puti russkogo bogosloviia [Paths of Russian Theology], (reprint of the Paris 1937 edition), Vil'nius, Litovskaia pravoslavnaia eparkhiia, 1991, 599 pp.

Gaidenko P.P., Vladimir Solov'ev i filosofiia Serebrianogo veka [Vladimir Solovyov and the Philosophy of the Silver Age], Moscow, Progress-Traditsiia, 2001, $472 \mathrm{pp}$.

Grom B., Ezoteryzm - nowa nadzieja? [Esotericism - A New Hope?], trans. U. Poprawska, Kraków, Wydawnictwo WAM, 2006, 203 pp.

Klimowicz T., Poszukujacy, nawiedzeni, opętani. Z dziejów spirytyzmu i okultyzmu $w$ literaturze rosyjskiej [The Seekers, Haunted, Possessed. From the History of Spiritualism and Occultism in Russian Literature], Wrocław, Wydawnictwo Uniwersytetu Wrocławskiego, 1992, 114 pp.

Klizovskii A., Osnovy miroponimaniia Novoi Epokhi [Fundamentals of New Age Worldview], Minsk, Zvezdy Gor, 2008, 800 pp.

Krasicki J., Bóg, człowiek i zło. Studium filozofii Włodzimierza Sołowjowa [God, Man and Evil. The Study of Philosophy by Vladimir Solovyov], Wrocław, Fun- 
dacja na Rzecz Nauki Polskiej, Wydawnictwo Uniwersytetu Wrocławskiego, 2003, 428 pp.

Kravchenko V., Vladimir Solov'ev i Sofiia [Vladimir Solovyov and Sofia], Moscow, AGRAF, 2006, $381 \mathrm{pp}$.

Kulianitsa D, Teosofiia E.P. Blavatskoi i russkaia literatura i iskusstvo (konets XIX - seredina XX veka) [H. Blavatsky's Theosophy and Russian Literature and Art (ending of the XIX - beginning of the XX centuries)], [in:] Sovremennoe miroponimanie: dukhovnye aspekty razvitiia kul tury. Materialy ezhegodnoi nauchno-prakticheskoi konferentsii "E.P. Blavatskaia i sovremennost'" [Modern World Outlook: Spiritual Aspects of the Development of Culture. Materials of the Annual Scientific and Practical Conference "H. Blavatsky and the Present"], Shabanova Iu.A., Prigunov A.S., Pavlenko I.V. (Eds.), Dnipropetrovsk, National Mining University, 2013, pp. 15-33.

Kuraev A., Satanizm dlia intelligentsii (O Rerikhakh i Pravoslavii v dvukh tomakh) [Satanism for Intellectuals (On the Roerichs and Orthodoxy in Two Volumes). Vol.2, Khristianstvo bez okkul'tizma, [Christianity Without the Occult], Moscow, Publishing House of the Moscow Metochion of the Holy Trinity Sergius Lavra, 2006, 429 pp.

Mazurek S., Dziedzictwo gnozy w rosyjskiej filozofii religijnej [Legacy of Gnosis in Russian Religious Philosophy]. Available at: http://www.ahf.ifispan.pl/pl/58mazurek-gnoza [accessed: 20.05.2021].

Nikol'skii E., Vzgliady Vsevoloda i Vladimira Solov'evykh na parafilosofskoe i literaturnoe nasledie Eleny Blavatskoi [The Views of Vsevolod and Vladimir Solovyov on the Paraphilosophical and Literary Legacy of Helena Blavatsky], "Sociopolitical Sciences" 2011, no. 1, pp. 99-101.

Papieska Rada Kultury, Papieska Rada do Spraw Dialogu Międzyreligijnego, Jezus Chrystus dawcq wody żywej. Chrześcijańska refleksja na temat New Age [Jesus Christ the Giver of Living Water. Christian Reflection on the New Age], Kraków, Wydawnictwo "M", 2003, 127 pp.

Przebinda G., Włodzimierz Sołowjow wobec historii [Vladimir Solovyov Towards History], Kraków, Arka, 1992, 245 pp.

Popova L., "Demonicheskoe" v khudozhestvennoi kul 'ture Serebrianogo veka: kul'turfilosofskie aspekty. Avtoreferat dissertatsii na soiskanie uchenoi stepeni kandidata kul'turologii, Gosudarstvennyi institut iskusstvoznaniia Ministerstva kul 'tury Rossiiskoi Federatsii ["The Demonic" in Artistic Culture of the Silver Age: Cultural and Philosophical Aspects. An autopresentation of a doctoral dissertation for $\mathrm{PhD}$ degree in Cultural Studies], Moscow, 2014, $26 \mathrm{pp}$.

Posacki A., Ezoteryzm i okultyzm - formy dawne i nowe. Aspekty filozoficzno-teologiczne i praktyczno-duszpasterskie [Esotericism and Occultism - Old and New 
Forms. Philosophical-Theological and Practical-Pastoral Aspects], Radom, Polskie Wydawnictwo Encyklopedyczne, 2009, 520 pp.

Posacki A., Neospirytyzm i pseudopsychologie [Neospiritualism and Pseudo-Psychologies], Kraków, Wydawnictwo „M”, 2012, 482 pp.

Sołowjow S. M., Życie i ewolucja twórcza Włodzimierza Solowjowa [The Life and Creative Evolution of Vladimir Solovyov], trans. E. Siemaszkiewicz, Poznań, W drodze, 1986, $395 \mathrm{pp}$.

Wójtowicz N., Masoneria [Freemasonry], Warszawa, Verbinum, 2006, 468 pp. 
